\title{
PERANCANGAN SISTEM INFORMASI ADMINISTRASI PEMBAYARAN PADA SDIT LAMPU IMAN KARAWANG BERBASIS VISUAL BASIC 6.0
}

\author{
${ }^{1}$ Ingrid Rosalia Dewi, ${ }^{2}$ Rini Malfiany \\ STMIK Rosma Karawang, Manajemen Informatika \\ ingridrosalia7@gmail.com, rini.malfiany@gmail.com
}

\begin{abstract}
ABSTRAK
Materi yang penulis ungkap dalam abstrak ini adalah mengenai Sistem Informasi Administrasi Pembayaran meliputi biaya SPP, Biaya Pendidikan, dan Buku Paket. Perancangan sistem informasi administrasi pembayaran pada SDIT Lampu Iman Karawang Berbasis Visual Basic bertujuan untuk mempermudah proses adminisrasi pembayaran menjadi lebih tepat akurat dan terkomputerisasi dengan basis penyimpanan database. Sistem informasi administrasi pembayaran ini diharapkan membantu tatausaha untuk menginput dan mengolah data dengan baik.

Metode yang digunakan dalam penulisan laporan tugas akhir ini yaitu : metode pengumpulan data dan pengembangan sistem. Metode pengumpulan data yang digunakan yaitu : studi literatur, observasi, wawancara dan dokumentasi sedangkan pengembangan sistem meliputi : masukan, keluaran, proses dan perancangan Visual Basic. Berdasarkan pengamatan yang telah penulis lakukan pada umumnya sistem informasi administarsi pembayaran di SDIT Lampu Iman Karawang sudah menggunakan sistem komputerisasi, tetapi masih mengadopsi pada Microsoft Excel sehingga sulit memperoleh informasi dalam waktu yang cepat, juga menyebabkan terlambatnya dalam pembuatan laporan. Berdasarkan permasalahan diatas, penulis berpendapat bahwa untuk mengatasi permasalah yang terjadi tersebut, perlu dirancang dan diimplementasikan suatu sistem administarsi pembayaran terkomputerisasi yang dapat tersimpan ke dalam database dengan menggunakan pemrograman Visual Basic 6.0 sebagai bahasa pemrogramannya MySQL yang dapat membantu pengguna sistem pada khususnya dalam administrasi pembayaran.
\end{abstract}

\section{Kata Kunci : Sistem Informasi Administrasi Pembayaran, Visual Basic 6.0}

\section{ABSTRACT}

The material in the abstract authors said this is the Payment Administration Information System covers tuition fees, education fees, and Discount Books. Administrative information system design payment on SDIT Lights Faith-Based Visual Basic Karawang aims to simplify the process administrasi payments become more precise and accurate computerized database storage base. Payment administration information system is expected to help Business Management to enter and process the data properly.

The method used in this research report writing include : methods of data collection and system development. Data collection methods used are : a literature study, observation, interviews and documentation while the development of the system include: input, output, process and design of Visual Basic. Based on the observation that has been done on a typical system administarsi payment information in Karawang Faith Lights SDIT already using a computerized system, but it still adopts Microsoft Excel making it difficult to obtain information in a short time, also led to delays in making the report. Based on the above problems, the author argues that in order to overcome the problems that occurred, need to be designed and implemented a system administarsi payment computerized that can be stored into the database by using Visual Basic 6.0 as the programming language MYSQL that can help users of the system, in particular in the administration of payments.

Keywords: Information Systems Payment Administration, Visual Basic 6.0 


\section{PENDAHULUAN}

Pelayanan administrasi pembayaran di SDIT Lampu Iman Karawang telah memakai sistem informasi berupa pemakaian perangkat komputer, tetapi masih mengadopsi sistem pada microsoft excel, sehingga data-datanya belum tersimpan kedalam database, sehingga sulit memperoleh informasi dalam waktu yang cepat juga menyebabkan terlambatnya dalam pembuatan laporan, dan nota transaksinya pun masih dicatat pada lembaran kertas menggunakan tulis tangan. Hal ini menimbulkan pemrosesan data informasi yang diperlukan oleh bagian administrasi menjadi tidak berjalan dengan baik.

Masalah-masalah tersebut disebabkan sistem administrasi belum tertata dengan baik, sehingga mengharuskan pihak sekolah untuk menerapkan sistem administrasi yang mampu memproses data secara tepat, akurat dan terkomputerisasi. Mampu menyimpan serta menampilkan yang berkaitan dengan sistem administrasi sehingga informasi yang dihasilkan lebih cepat, akurat dan terkelola dengan baik.

Sistem informasi administrasi pembayaran merupakan suatu kegiatan yang membantu dalam layanan pembayaran pada kegiatan administrasi sekolah yang membutuhkan pengolahan administrasi pembayaran yang terkomputerisasi, sehingga layanan informasi administrasi pembayaran tersebut dapat dilakukan dengan cepat dan efisien. Administrasi pembayaran yang ada pada SDIT Lampu Iman Karawang terdiri dari SPP, Biaya Pendidikan, dan Buku Paket.

Permasalahan tersebut disebabkan sistem pendukung keputusan dalam pengolahan administrasi pembayaran belum mampu menyimpan kedalam database, maka diperlukannya sistem yang baru untuk menggatikan sistem yang sedang berjalan yaitu dengan membuat suatu Aplikasi Perancangan Sistem Informasi Administrasi Pembayaran, karena sistem yang akan dihasilkan lebih mudah untuk beradaptasi dengan perubahan kebutuhan dan mudah untuk dipelihara dan mendukung desain yang lebih komplek/lengkap yang diharapkan dapat menyelesaikan permasalahan yang ada pada sistem informasi administrasi pembayaran.

\section{TINJAUAN PUSTAKA}

\section{Perancangan}

Menurut

Pressman

(2010:399), "perancangan adalah langkah pertama bagi setiap produk atau sistem yang di rekayasa".

Menurut Mohamad Subhan (2012:109), "perancangan adalah proses pengembangan spesifikasi baru berdasarkan rekomendasi hasil analisis sistem".

\section{Pengertian Sistem}

Menurut McLeod dalam Yakub (2012:1), "sistem adalah sekelompok elemen-elemen yang terintegrasi dengan tujuan tujuan yang sama untuk mencapai tujuan. Sistem juga merupakan suatu jaringan kerja dari prosedurprosedur yang saling berhubungan, terkumpul bersama-sama untuk melakukan suatu kegiatan atau untuk tujuan tertentu".

Menurut Edhy Sutanta (2011:4), "sistem adalah sekumpulan hal atau kegiatan atau elemen atau subsistem yang saling bekerja sama atau yang dihubungkan dengan cara-cara tertentu sehingga membentuk satu kesatuan untuk melaksanakan suatu fungsi guna mencapai suatu tujuan".

\section{Pengertian Informasi}

Menurut McLeod dalam (Yakub, 2012:8), "informasi adalah data yang diolah menjadi bentuk lebih berguna dan lebih berarti bagi yang menerimanya”.

Menurut Bambang Hartono (2011:66), "informasi merupakan data yang telah diolah sehingga menjadi suatu bentuk yang penting yang berguna bagi penerimanya dan mempunyai kegunaan sebagai dasar dalam pengambilan keputusan yang dapat dirasakan akibatnya secara langsung atau secara tidak langsung dimasa yang akan datang".

\section{Pengertian Sistem Informasi}

Menurut O'Brian dalam Yakub (2012:17), "sistem Informasi adalah kombinasi teratur dari orang-orang, perangkat keras (hardware), perangkat lunak (software), 
jaringan komunikasi dan sumber daya data yang mengumpulkan, mengubah dan menyebarkan informasi dalam sebuah organisasi"

Menurut Dr. Azhar Susanto (2010:22), "sistem Informasi adalah kumpulan dari subsistem baik fisik maupun non fisik yang saling berhubungan satu sama lain dan bekerja sama secara harmonis untuk mencapai satu tujuan yaitu mengolah data menjadi informasi yang berguna".

\section{Pengertian Administrasi}

Menurut Lagin (2010:19), “administrasi adalah sebagai keseluruhan proses kerja sama antara dua orang atau lebih yang didasarkan atas rasionalitas tertentu untuk mencapaitujuan yang telah ditentukan sebelumnya".

\section{Pengertian Visual Basic 6.0}

Menurut Ridwan Sanjaya dalam Hamdan (2012:12), "visual basic 6.0 adalah sebuah bahasa pemograman yang menawarkan Intregated Development Environment (IDE) yang didalamnya berisi perintah-perintah yang dapat dimengerti oleh komputer. Visual Basic 6.0 ini pun telah menjadi bahasa pemograman visual yang paling popular dan mudah untuk dipelajari.

\section{Pengertian Database}

Menurut Edy Winarno, M.Eng, Ali Zaki, dan SmitDev Community (2013:117), "database adalah kumpulan informasi yang disimpan di dalam komputer secara sistematik sehingga dapat diambil datanya atau diolah mengunakan suatu program".

Menurut Fathansyah (2012:2), "basis data terdiri atas 2 kata, yaitu basis dan data. Basis kurang lebih dapat diartikan sebagai markas atau gudang, tempat bersarang atau berkumpul. Sedangkan data adalah representasi fakta dunia nyata yang mewakili suatu objek seperti manusia, barang, hewan, peristiwa, konsep dan sebagainya".

\section{Pengertian My SQL}

Menurut Arief Rudianto (2011:152), "MySQL merupakan database yang pertama kali didukung oleh bahasa pemrograman script untuk internet (PHP dan Perl). MySQL dan PHP dianggap sebagai pasangan software pembangun aplikasi web yang ideal. MySQL lebih sering digunakan untuk membangun aplikasi berbasis web, umumnya pengembangan aplikasinya menggunakan bahasa pemrograman script PHP.

Menurut Antonius Nugraha (2010:10), "MySQL adalah suatu sistem manajemen basis data relasional yang mampu bekerja dengan cepat, kokoh, dan mudah digunakan".

\section{Pengertian Xampp}

Menurut Bunafit Nugroho (2011:1), "XAMPP merupakan paket PHP berbasis open source yang dikembangkan oleh komunitas Open Source, yang mendukung banyak sistem operasi, merupakan kompilasi dari beberapa program. Fungsinya adalah sebagai server yang berdiri sendiri (localhost), yang terdiri atas program Apache HTTP Server, MySQL database, dan penerjemah bahasa yang ditulis dengan bahasa pemrograman PHP dan Perl. Nama XAMPP merupakan singkatan dari X (empat sistem operasi apapun), Apache, MySQL, PHP dan Perl. Program ini tersedia dalam GNU General Public License dan bebas, merupakan web server yang mudah digunakan yang dapat melayani tampilan halaman web yang dinamis.

Menurut Imansyah (2010:4), "XAMPP adalah installer yang membundel Apache, PHP, dan MySQL untuk Windows dalam satu paket”.

\section{Pengertian Pembayaran}

Menurut Undang-Undang Nomor 23 tentang Bank Indonesia (Pasal 1 angka 6) dalam Eka Rini Handayani (2015:49), "menjelaskan sistem pembayaran yaitu sistem yang mencakup seperangkat aturan, lembaga dan mekanisme yang digunakan untuk melaksanakan pemindahan dana guna memenuhi suatu kewajiban yang timbul dari suatu kegiatan ekonomi. Sistem Pembayaran merupakan sistem yang berkaitan dengan pemindahan sejumlah nilai uang dari satu pihak ke pihak lain. Media yang digunakan untuk pemindahan nilai uang tersebut sangat beragam, mulai dari penggunaan alat pembayaran yang sederhana sampai pada penggunaan sistem yang kompleks 
dan melibatkan berbagai lembaga berikut aturan mainnya. Kewenangan mengatur dan menjagakelancaran sistem pembayaran di Indonesia dilaksanakan oleh Bank Indonesia yang dituangkan dalam Undang-undang Bank Indonesia".

Menurut Tirto Waluyo dalam Eka Rini Handayani (2015:49), "pembayaran adalah suatu tindakan menukarkan sesuatu (uang/barang) dengan maksud dan tujuan yang sama yang dilakukan oleh dua orang atau lebih".

\section{Entitas Relantionship Diagram (EFD)}

Menurut Dolly Indra (2010:3), "ERD (Entitas Relantionship Diagram) adalah suatu cara untuk menjelaskan kepada para pemakai tentang hubungan antar data dalam basis data secara logic dengan persepsi bahwa real world terdiri dari objek-objek dasar yang saling berhubungan dengan cara menvisualisasikan ke dalam bentuk simbol-simbol grafis".

\section{Pengertian Kamus Data}

Menurut Tata Sutabri (2012: 19), "Kamus Data adalah Kamus Data dibuat berdasarkan arus data yang ada pada Data Flow Diagram. Arus data yang ada di DFD bersifat global dan hanya menunjukkan nama arus datanya saja".

\section{Pengertian Flowchart}

Menurut Bambang Hartono (2011:144), "flowchart merupakan penggambaran dari grafik dari langkah-langkah atau bagian yang memperlihatkan urutan- urutan prosedur dari suatu program dan hubungan antara proses beserta bentuknya". Gambar flowchart dinyatakan dengan simbol, dengan demikian setiap simbol menggambarkan proses tertentu, sedangkan hubungan antar proses digambarkan dengan garis penghubung. Flowchart menolong analisis dari programmer untuk memecahkan masalah kedalam segmen-segmen lebih kecil dan dalam menganalsis alternatif-alternatif lain dalam pengoperasian.

\section{Pengertian DFD (Data Flow Diagram)}

Menurut Bambang Hartono (2011:56), "data flow diagram (DFD) adalah suatu diagram yang menggunakan notasi-notasi untuk menggambarkan arus dari data sistem, yang penggunaanya sangat membantu untuk memahami sistem logika, terstruktur dan jelas".

Menurut James A. Hall (2010:1), "data Flow Diagram (DFD) adalah Data Flow Diagram adalah Suatu diagram yang menggunakan simbol-simbol untuk mencerminkan proses, sumber-sumber data, arus data dan entitas dalam sebuah sistem".

\section{METODOLOGI PENELITIAN}

Metodologi penelitian ini menjelaskan mengenai metode pengumpulan data dan metode perancangan data.

\section{Pengumpulan Data}

Pengumpulan data yang digunakan adalah sebagai berikut :

\section{Wawancara}

Peneliti melakukan wawancara dengan Bapak Ahmad Nashruddin Shalih, S.Pd.I. selaku wakasek kurikulum yang bertujuan untuk memudahkan penulis dalam mencari dan mendapatkan informasi yang dibutuhkan, yaitu dalam pengumpulan data, identifikasi masalah, pemecahan masalah dan untuk memudahkan dalam membuat atau menyusun laporan.

2. Observasi

Metode ini dipakai untuk mendapatkan data yang dapat dilihat dan diamati secara langsung mengenai Sistem Informasi Administrasi Pembayaran pada SDIT Lampu Iman Karawang. Adapun jenis pembayaran yang ada di SDIT Lampu Iman antara lain Biaya Pendidikan, SPP, dan Buku Paket.

3. Dokumentasi

Dokumentasi ini berupa dokumen-dokumen yang dapat memberikan keterangan atau bukti berkaitan dengan proses pengumpulan dan pengelolaan dokumen secara sistematis yang terdiri dari :
a. Data Siswa
b. Rincian Pembayaran Biaya Pendidikan dan Daftar Harga Buku Paket
c. Bukti Pembayaran 
4. Studi Literatur

Metode ini dipakai untuk mendapatkan data dengan cara memperoleh sumber-sumber informasi dari media cetak ataupun internet yang berhubungan dengan penulisan laporan.

\section{Metode Perancangan Data}

Metode perancangan data yang digunakan adalah metode yang terstruktur dengan melalui tahapan sebagai berikut :

1. DFD (Data Flow Diagram)

2. Diagram Overview

3. Diagram Rinci

4. Kamus Data

5. ERD (Entitas Relationship Diagram)

6. Rancangan Database

\section{IDENTIFIKASI DAN PERANCANGAN}

\section{Riwayat SDIT Lampu Iman Karawang}

SDIT Lampu Iman Karawang adalah sekolah dasar islam terpadu yang bertempat/berlokasi di kota Karawang dan beralamat di Jalan Dr. Taruno No.149, Adiarsa Barat, Karawang Barat, dan SDIT Lampu Iman Karawang memilki data diantaranya, sejarah singkat, visi dan misi.

\section{Hasil Temuan/Permasalahan}

Setelah mengidentifikasi sistem yang sedang berjalan, maka didapat permasalahan yang ditemui pada sistem informasi administrasi pada SDIT Lampu Iman Karawang, yaitu masih mengadopsi pada Microsoft Excel, sehingga data-datanya belum tersimpan kedalam DataBase, sehingga sulit memperoleh informasi dalam waktu yang cepat juga menyebabkan terlambatnya bagian Tata Usaha dalam pembuatan laporan. Untuk memecahkan permasalahan tersebut maka dibuat sistem pendukung keputusan dari sistem yang sedang berjalan.

\section{Solusi Pemecahan Masalah}

Berdasarkan hasil identifikasi dapat disimpulkan bahwa administrasi pembayaran di SDIT Lampu Iman belum tersimpan kedalam DataBase, karenanya diperlukan sebuah sistem yang dapat mendukung dalam sistem informasi administrasi ini. Kemudian penulis mencoba untuk membuat dan merancang sistem administrasi. Sehingga nantinya sistem administrasi ini dapat membantu, merpercepat dan merpermudah bagian Tata Usaha.

\section{Flowmap Usulan Sistem Administrasi} Pembayaran

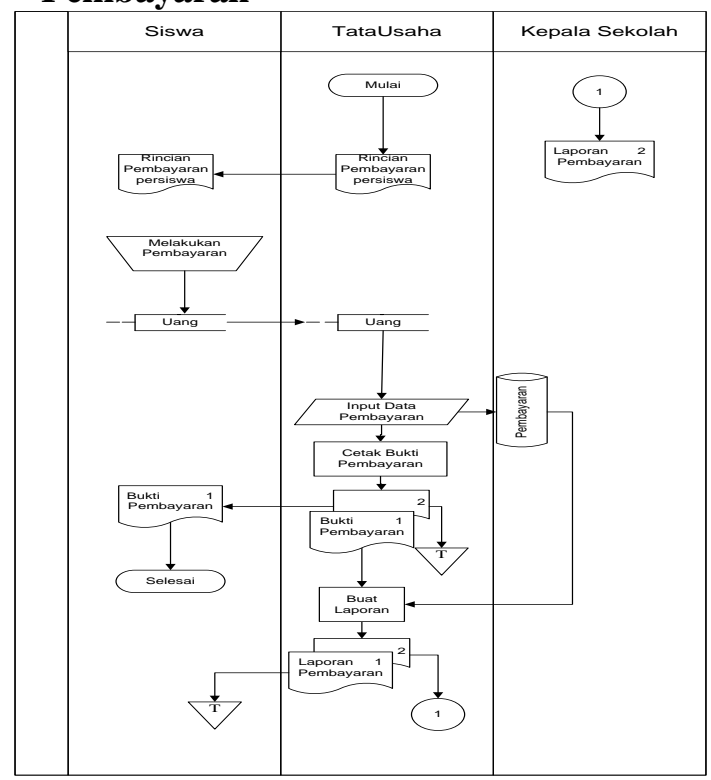

Gambar 1 Flowmap Usulan Sistem Administrasi Pembayaran

\section{Flowmap Usulan Sistem Administrasi Pembayaran Tunggakan}

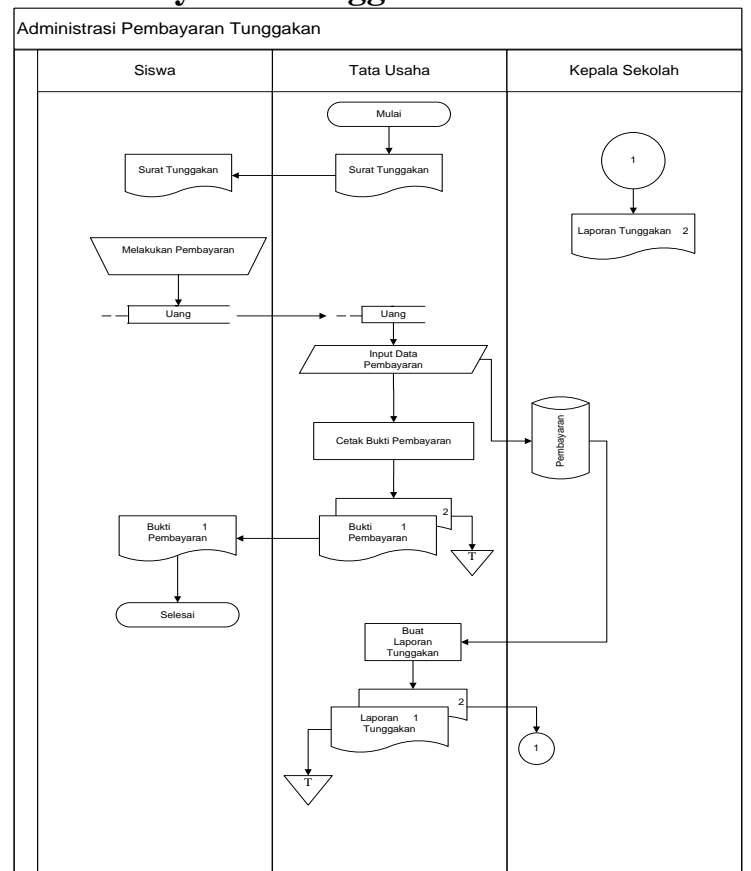

Gambar 2. Flowmap Usulan Sistem Administrasi Pembayaran Tunggakan 


\section{Diagram Konteks}

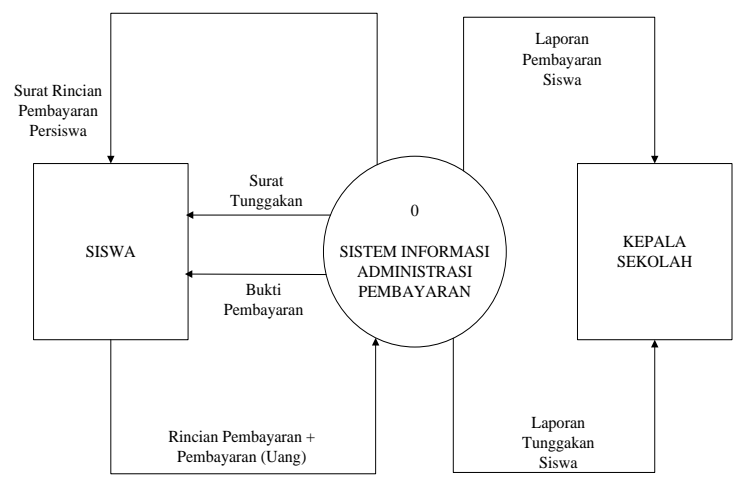

Gambar 3. Diagram Konteks Sistem Administrasi pembayaran

\section{Diagram Overview}

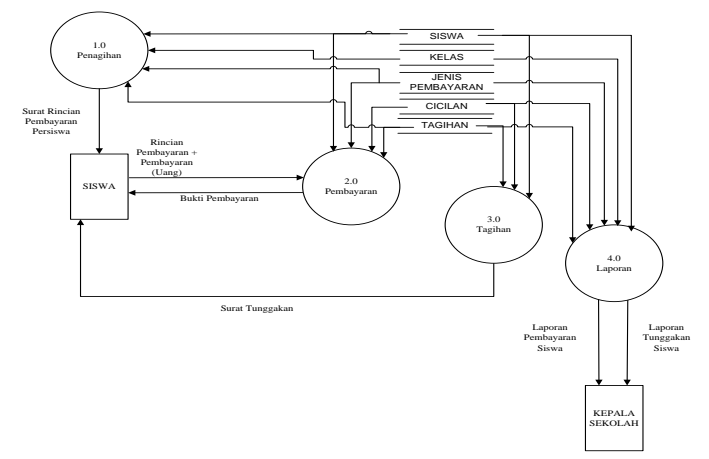

Gambar 4. Diagram Overview Sistem Adminstrasi Pembayaran

\section{ERD}

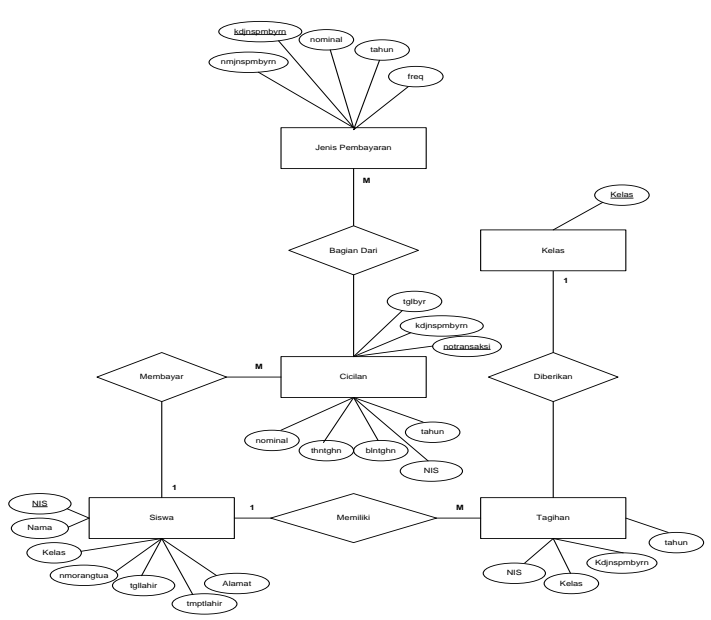

Gambar 5. ERD Sistem Administrasi Pembayaran

\section{IMPLEMENTASI SISTEM}

\section{Rancangan Masukan}

Sistem usulan memiliki beberapa input sebagai berikut :

1. Form Masuk (login)

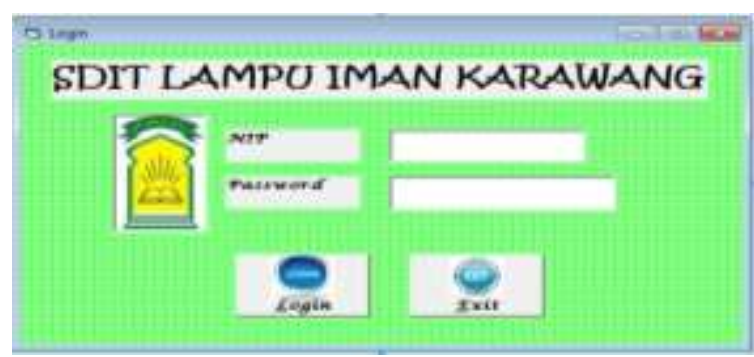

Gambar 6

Tampilan Aplikasi Form Login

2. Rancangan Menu Utama

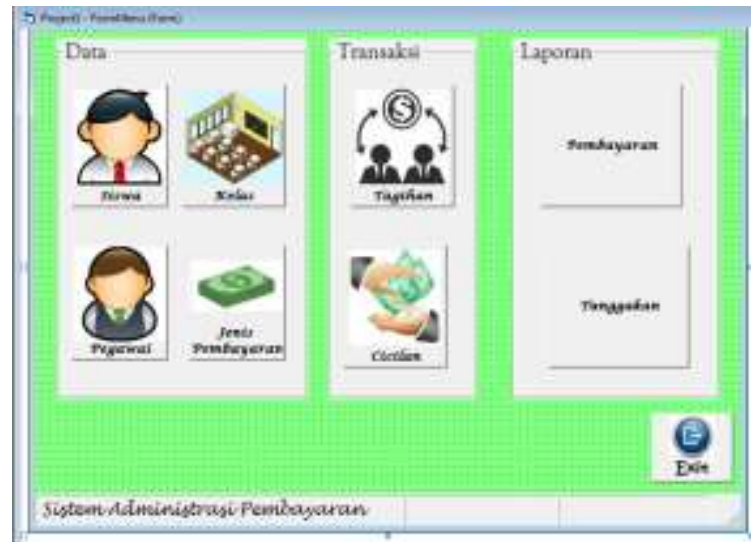

Gambar 7. Tampilan Aplikasi Form Menu Utama

3. Rancangan Data Siswa

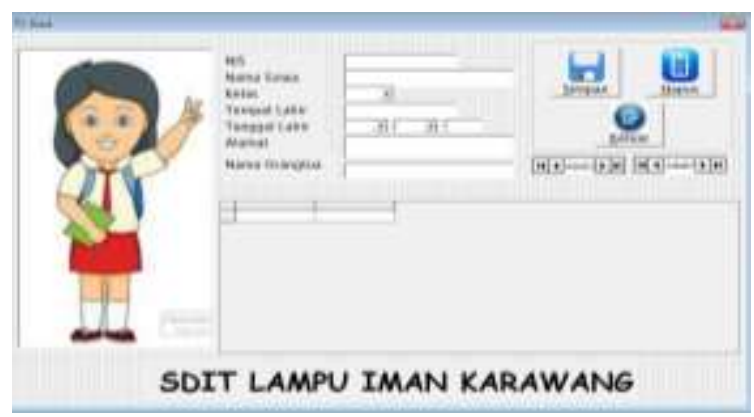

Gambar 8. Tampilan Aplikasi Form Siswa 
4. Rancangan Data Kelas

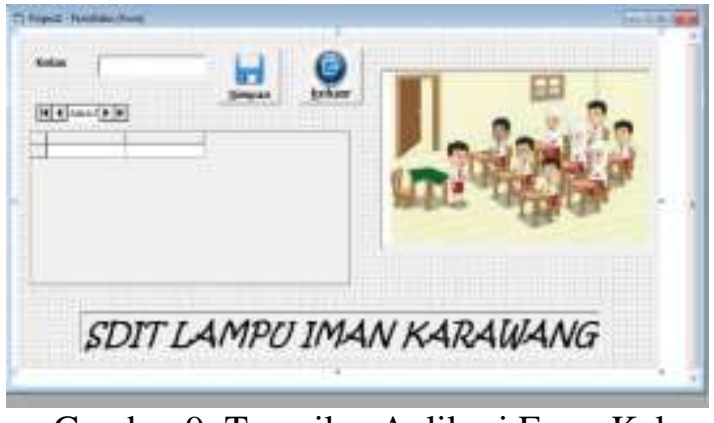

Gambar 9. Tampilan Aplikasi Form Kelas

5. Rancangan Data Pegawai

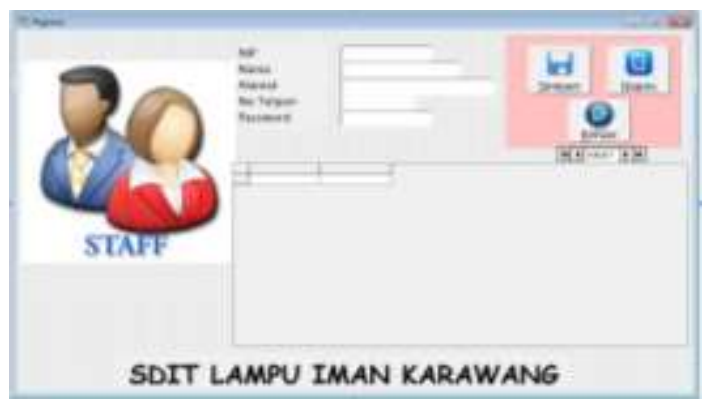

Gambar 10. Tampilan Aplikasi Form Pegawai

6. Rancangan Data Jenis Pembayaran

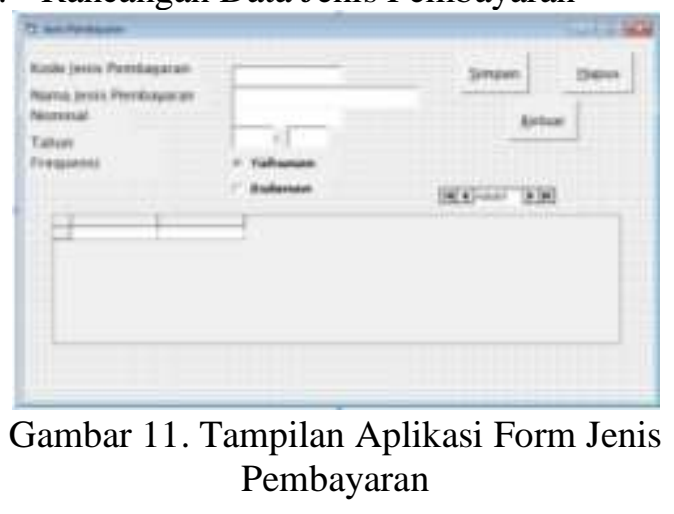

7. Rancangan Transaksi Tagihan

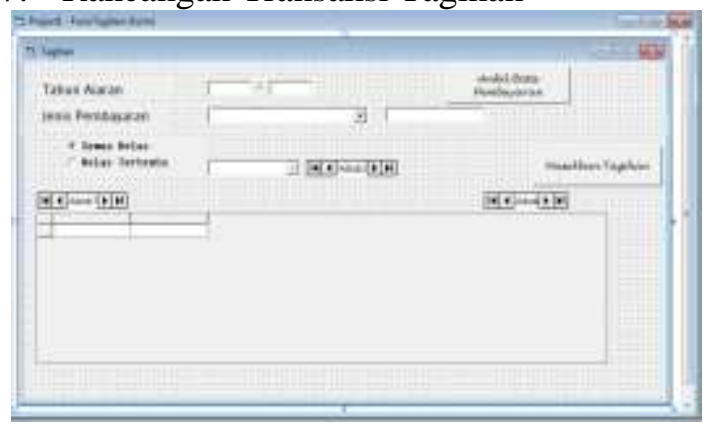

Gambar 12. Tampilan Aplikasi Form Tagihan
8. Rancangan Transaksi Cicilan

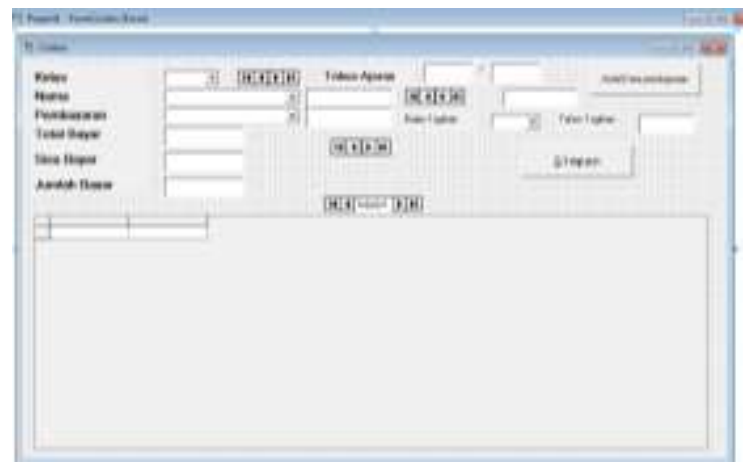

Gambar 13. Tampilan Aplikasi Form Cicilan

\section{Rancangan Laporan Pembayaran}

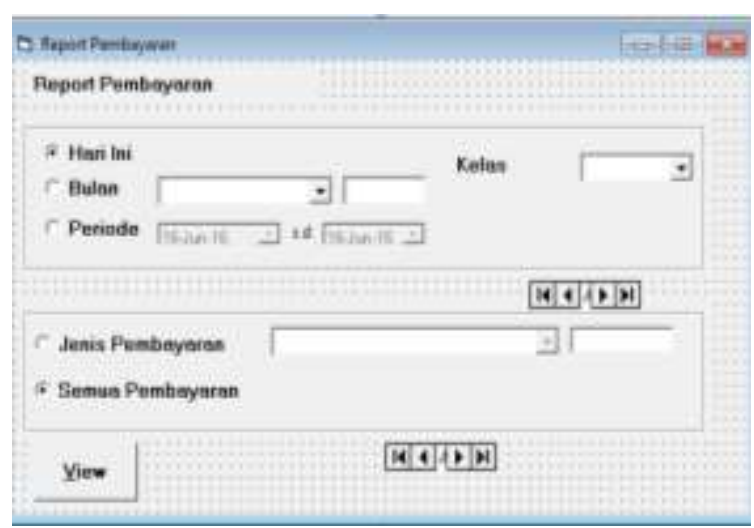

Gambar 14. Tampilan Aplikasi SetRep Pembayaran

\section{Rancangan Laporan Pembayaran Tunggakan}

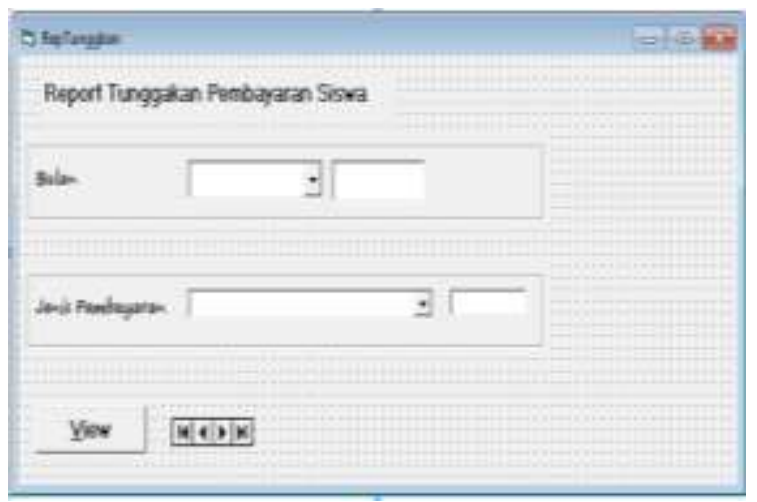

Gambar 15. Tampilan Aplikasi SetRep Tunggakan 


\section{Rancangan Keluaran}

1. Rancangan Form Siswa

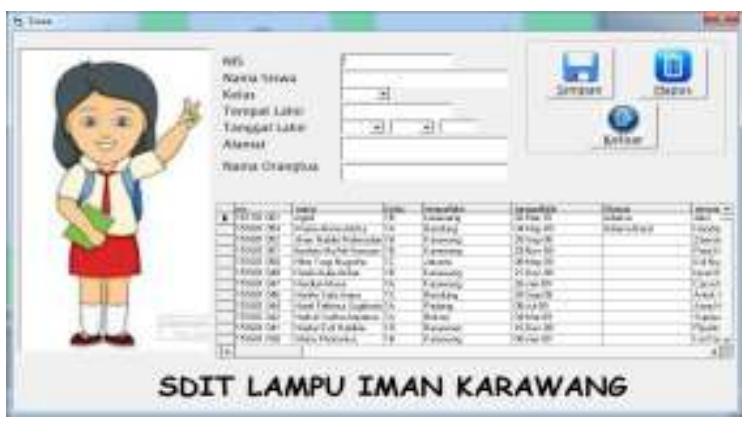

Gambar 16. Form Siswa

2. Rancangan Form Kelas

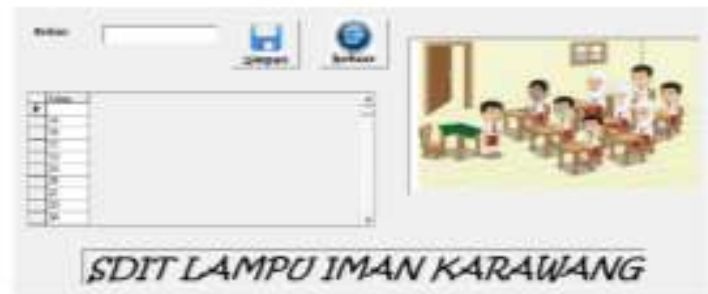

Gambar 17. Form Kelas

3. Rancangan Form Pegawai

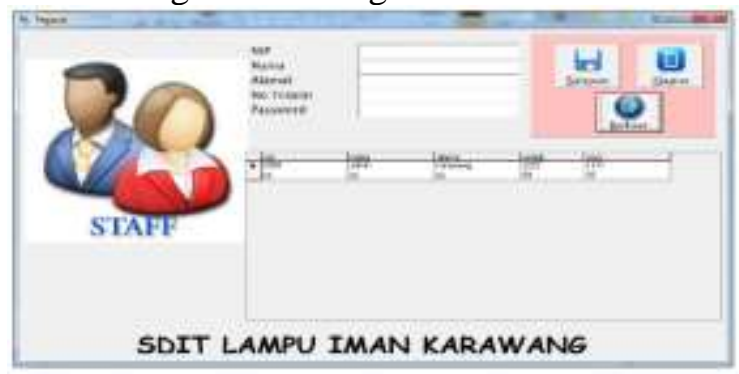

Gambar 18. Form Pegawai

4. Rancangan Form Jenis Pembayaran

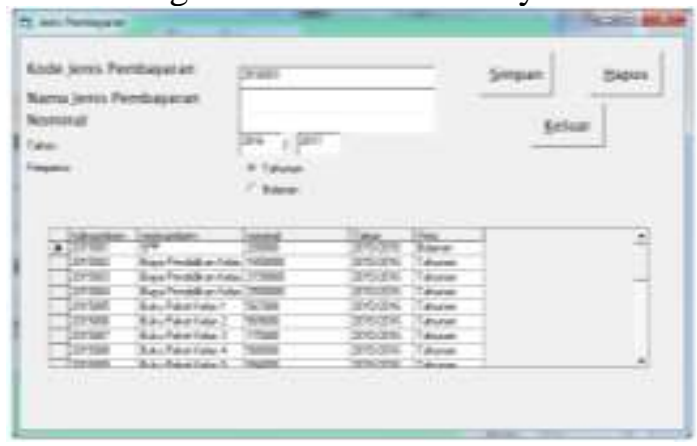

Gambar 19. Form Jenis Pembayaran
5. Rancangan Form Transaksi Tagihan

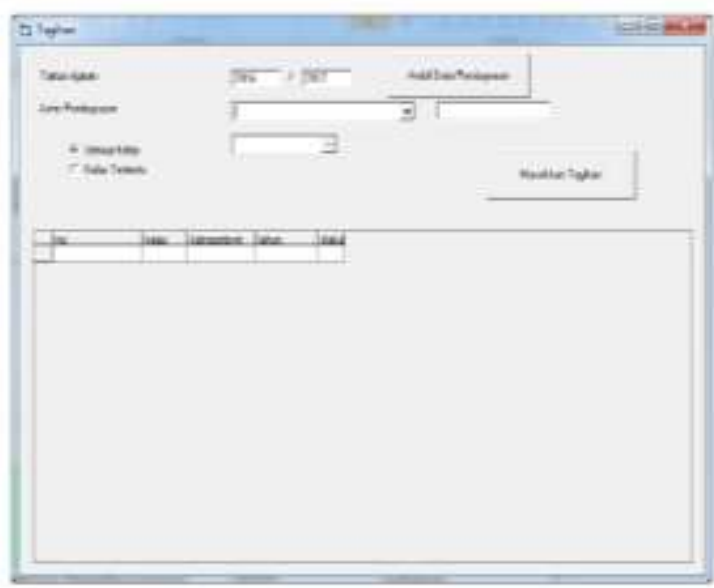

Gambar 20. Form Transaksi Tagihan

6. Rancangan Form Transaksi Cicilan

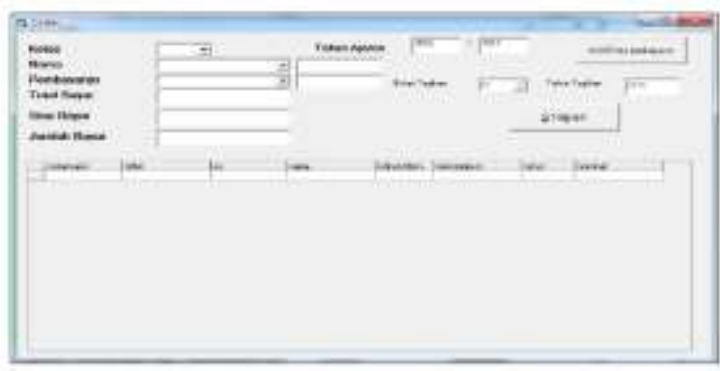

Gambar 21. Form Transaksi Cicilan

\section{KESIMPULAN DAN SARAN}

\section{Kesimpulan}

Setelah melakukan penelitian di SDIT Lampu Iman Jalan dr. Taruno No.149, Adiarsa Barat, Karawang Barat, maka penulis dapat mengambil kesimpulan sebagai berikut :

1. Sistem administrasi di SDIT Lampu Iman Karawang yang masih menggunakan sistem pada Microsoft Excel diganti dengan menggunakan Visual Basic 6.0 dan Sql Server 2005 sebagai Databasenya, karena jika masih menggunakan sistem

2. pada Microsoft Excel data-datanya belum tersimpan kedalam database.

3. Nota transaksinya masih dicatat pada lembaran kertas menggunakan tulis tangan. Hal ini menimbulkan pemrosesan data informasi yang diperlukan oleh bagian 
administrasi menjadi tidak berjalan dengan baik.

4. Dengan diterapkannya sistem baru yang akan digunakan pada SDIT Lampu Iman Karawang ini diharapkan dapat meningkatkan kegiatan operasional secara lebih cepat dan akurat.

\section{SARAN}

Adapun saran yang diusulkan penulis untuk meningkatkan sistem administrasi di SDIT Lampu Iman Karawang diantaranya :

1. Dengan semakin majunya perkembangan teknologi diharapkan SDIT Lampu Iman Karawang dapat menggunakan komputer yang lebih maksimal yaitu dengan peningkatan sumber daya manusia yang handal.

2. Sebaiknya SDIT Lampu Iman Karawang ke depannya dapat mengidentifikasi lebih detail sistem administrasi mengenai biaya pendidikan dalam pendataan pembayaran siswa.

3. Semoga SDIT Lampu Iman Karawang ke depannya dapat memproses semua kegiatan administrasi dengan baik menggunakan sistem yang ada, tidak hanya biaya pendidikan, SPP, dan Buku Paket

4. Sistem administrasi ini sebaiknya segera direalisasikan guna mendukung kegiatan administrasi yang dilakukan setiap harinya.

\section{DAFTAR PUSTAKA}

Fathansyah. 2012. Basis Data. Bandung : Informatika.

Hall, James A. 2010. Sistem Informasi Akuntansi. Yogyakarta : Andi.

Hamdan. 2012. Pengenalan Microsoft Visual Basic 6.0. Bogor: Ghalia Indonesia

Handayani, Eka Rini. 2015. Jurnal Perancangan Sistem Informasi Pengolahan Data Pembayaran Siswa Terkomputerisasi pada Bimbingan Belajar dan Konseling Galileo Institute di Tangerang.

Hartono, Bambang. 2012. Sistem Informasi Manajemen Berbasis Komputer. Jakarta : Rinerka Cipta.
Hayati, Mafrida Rofiul, Migunani, fitro Nur Hakim. 2013. Sistem Informasi Pembayaran Spp Berbasis Web Dan Sms Broadcast. Vol. 4 No.2 ISSN:20870868.

Imansyah. 2010. Cara Praktis Membangun Website Gratis. Jakarta : PT Elex Media Komputindo

Indra, Dolly. 2010. Analisi dan Desain. Jakarta : PT Elex Media Kompotindu.

Lagin. 2010. Filsafat Administrasi. Jakarta : PT Elex Media Kompotindu.

Nugraha, Antonius. 2010. Aplikasi Web Database Dengan Dreamweaver dan PHP MySQL. Yogyakarta : Andi

Nugroho, Bunafit. 2011. Membuat Sistem Informasi Penjualan Berbasis Web. Jakarta : PT Elex Media Komputindo.

Pressman. 2010. Perancangan Sistem Informasi. Yogyakarta : Andi

Rudianto, Arief. 2010. Pemograman Web Dinamis Menggunakan PHP dan MySQL. Yogyakarta : Graha Ilmu.

Subhan, Mohamad. 2012. Analisa Perancangan Sistem. Yogyakarta : Andi

Sudirman, Hilman, Eko Retnadi, Rina Kurniawati. 2012. Perancangan Program Aplikasi Transaksi Pembayaran Spp, Uts Dan Uas Menggunakan Metode Analisis Dan Desain Berorientasiobjek Model Unified Approach (Ua). Vol. 19 No.18 ISSN : 2302-7339.

Susanto, Azhar. 2011. Sistem Informasi Manajemen. Bandung : Lingga Jaya

Sutabri, Tata. 2012. Analisa Sistem Informasi. Yogyakarta : Andi.

Sutanta, Edhy. 2011. Sistem Informasi Manajemen. Yogyakarta : Andi

Winarno, Edy, M.Eng, Ali Zaki, SmitDev Community. 2013.2 Belajar Pemrograman VB6 dalam Sekejap. Jakarta : PT Elex Media Komputindo.

Yakub. 2012. Pengantar Sistem Informasi. Yogyakarta : Graha Ilmu 